\title{
Pentacyclic Triterpenes from the Ethyl Acetate Fraction of the Bark of Platanus acerifolia Wild and Antitumor Activities In Vitro
}

Heng-Zhi Wang ${ }^{1}$, Chuan-Jin Wang ${ }^{2 *}$ and Wei $\mathrm{Li}^{2}$

${ }^{1}$ Nanjing No. 1 Middle School, Nanjing 210028, China

${ }^{2}$ Department of Pharmaceutical Engineering, Institute of Chemical Engineering, Nanjing University of Science and Technology, Nanjing 210094, China

\begin{abstract}

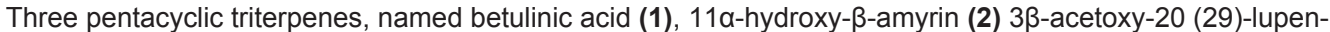
28-aldehyde (3) were isolated from the ethyl acetate fraction of the bark of Platanus acerifolia Willd. The molecular structure of 1 and were established on the basis of various spectroscopic analyses. The molecular structure of (3) was determined by single-crystal X-ray diffraction. Compound (2) and (3) were obtained from the title plant for the first time. Cytotoxicity of the isolated compounds against three human cancer cell lines, HepG-2, MCF-7 and HL-60 were also determined with the cell counting kit-8 (CCK-8) assay. The target compounds showed the high cytotoxicity, with $I_{50}$ values in the range 2.2-9.1 $\mu \mathrm{M}$. These results indicated that pentacyclic triterpenes from the bark of Platanus acerifolia Willd could be explored as potential cancer prevention agents.
\end{abstract}

Keywords: Pentacyclic triterpenes; Platanus acerifolia Willd bark; Antitumor activity in vitro

\section{Introduction}

Platanus acerifolia Willd, one of the famous street and garden trees, is a very large, wide spreading, and long-lived hardwood species native to Eurasia [1]. The bark of Platanus acerifolia Willd has been used as the traditional Chinese medicine in the treatment of dysentery, diarrhea, toothache and tumor [2]. In order to find some bioactive compounds, the chemical constituents of Platanus acerifolia Willd bark were investigated and three compounds, named betulinic acid (1), 11 $\alpha$-hydroxy- $\beta$-amyrin (2) and $3 \beta$-acetoxy-20 (29)-lupen-28aldehyde (3) were isolated. The structures of the three compounds were identified by their physicochemical properties and spectral analysis. In addition, the isolated compounds were also evaluated for cytotoxic efficacy against HepG-2, MCF-7 and HL-60 cell lines in vitro.

\section{Materials and Methods}

\section{General experimental procedures}

Melting points were determined on $\mathrm{RD}-2$ micromelting point apparatus and are uncorrected. The ${ }^{1} \mathrm{HNMR}(500 \mathrm{MHz})$ and ${ }^{13} \mathrm{C}$ NMR (500 MHz) spectra were recorded on a Bruker Avance III-500 spectrometer and tetramethylsilane (TMS) was used as an internal standard. Silica gel (200-300 mesh for Column Chromatography (CC) and $\mathrm{GF}_{254}$ for TLC) was obtained from Qingdao Marine Chemical Company (Qingdao, China). Sephadex LH-20 was obtained from Amersham Biosciences (Uppsala, Sweden). Single-crystal structure of compound 2 was measured on an Enraf-Nonius CAD4 diffractometer etc.

\section{Plant material}

The bark of Platanus acerifolia Willd was collected in Nanjing County, Jiangsu Province, China, in January 2010.

\section{Extraction and isolation}

The dried barks of Platanus acerifolia Willd (100 g) were cut into small pieces and extracted with EtOAc ( 1 liter $\times 3)$. The solvent was removed by rotary evaporation and the yellow brown extract $(4.0 \mathrm{~g})$ was obtained. The EtOAc extract was subjected to silica gel chromatography using stepwise elution with petroleum ether- $\mathrm{CH}_{3} \mathrm{COCH}_{3}$ (100:0, 100:1, $100: 2,100: 4,100: 8,100: 16,100: 32,100: 100$, and 0:100) to afford 90 fractions (F1-F90). F51-F60 (A) was permeated through Sephadex $\mathrm{LH}-20$ using a $\mathrm{MeOH}-\mathrm{CH}_{3} \mathrm{Cl}(1: 1)$ system to give 10 subfractions A1-
A10. Fractions A4-A6 were further purified with recystallization with $\mathrm{CH}_{3} \mathrm{Cl}-\mathrm{CH}_{3} \mathrm{COCH}_{3}$ (1:1) system to afford compound (1) (1000 mg); Fraction of $\mathrm{F} 8$ was further purified with recystallization with $\mathrm{CH}_{3} \mathrm{Cl}$ $\mathrm{CH}_{3} \mathrm{COCH}_{3}-\mathrm{MeOH}$ (1:1:1) system to afford compound (2) (10 mg); F11-F20 (B) were permeated through Sephadex LH-20 using a MeOH$\mathrm{CH}_{3} \mathrm{Cl}(1: 1)$ system to give 12 subfractions B1-B12. Fractions B4-B7 were further purified with recystallization with EtOAc-MeOH (1:1) system to afford compound (3) $(20 \mathrm{mg})$.

\section{Compounds identification}

Compound (1): Compound (1) was readily identified as betulinic acid by the analysis of their NMR spectra and by the comparison with the data reported in literature [3]. ${ }^{1} \mathrm{H}-\mathrm{NMR}(500 \mathrm{MHz}, \mathrm{DMSO}) \delta_{\mathrm{H}}=$ 12.08 (1H, brs, H-28), 4.69 (1H, brs, H-29a), 4.56 (1H, brs, H-29b), 4.28 (1H, brs, H-3), 1.64 (3H, s, H-30), 0.93 (3H, s, H-23), $0.88(3 \mathrm{H}$, s, H-27), 0.87 (3H, s, H-26), $0.76(3 \mathrm{H}, \mathrm{s}, \mathrm{H}-24), 0.68(3 \mathrm{H}, \mathrm{s}, \mathrm{H}-25)$; ${ }^{13} \mathrm{C}-\mathrm{NMR}(500 \mathrm{MHz}, \mathrm{DMSO}) \delta_{\mathrm{C}}=180.0$ (C-28), 150.3 (C-20), 109.5 (C-29), 76.8 (C-3), 55.4 (C-17), 54.9 (C-5), 55.4 (C-5), 49.9 (C-9), 48.5 (C-19), 46.6 (C-18), 42.0 (C-14), 40.2 (C-8), 38.5 (C-4), 38.2 (C-1), 37.5 (C-13), 36.7 (C-10), 36.4 (C-22), 33.9 (C-7), 31.7 (C-16), 30.1 (C-15), 29.2 (C-21), 28.1 (C-23), 27.1 (C-2), 25.1 (C-12), 20.4 (C-11), 18.9 (C30), 17.9 (C-6), 15.9 (C-26), 15.8 (C-24, 25), 14.4 (C-27).

Compound (2): The acicular crystal of $11 \alpha$-hydroxy- $\beta$-amyrin was recrystallized in the mixture solution of $\mathrm{CH}_{3} \mathrm{Cl}-\mathrm{CH}_{3} \mathrm{COCH}_{3}-\mathrm{MeOH}$ (1:1:1), and single crystal was obtained in constant temperature $\left(25^{\circ} \mathrm{C}\right)$ on the basis of this. m.p: $234 \sim 236^{\circ} \mathrm{C}$. Elemental Anal. Calcd. (\%) for $\mathrm{C}_{30} \mathrm{H}_{50} \mathrm{O}_{2}: \mathrm{C}, 81.39 ; \mathrm{H}, 11.38 ; \mathrm{O}, 7.23$. Found (\%): C, 81.20; H, 11.48; O, 7.32. ${ }^{1} \mathrm{H}-\mathrm{NMR}\left(500 \mathrm{MHz}, \mathrm{CDCl}_{3}\right) \delta_{\mathrm{H}}=5.24(1 \mathrm{H}, \mathrm{d}, \mathrm{H}-12), 4.21(1 \mathrm{H}, \mathrm{dd}$, H-11), 3.22 (1H, dd, H-3), 2.06 (1H, m, H-18), 1.94 (2H, m, H-21), 1.23 (3H, s, H-23), 1.08 (3H, s, H-27), 1.02 (3H, s, H-25), 1.02 (3H, s, H-26),

*Corresponding author: Chuan-Jin Wang, Department of Pharmaceutical Engineering, Institute of Chemical Engineering, Nanjing University of Science and Technology, Nanjing, 210094, China, Tel: +862584315514; E-mail: wangchuanjin@njust.edu.cn

Received February 11, 2016; Accepted March 27, 2016; Published March 31 2016

Citation: Wang HZ, Wang CJ, Li W (2016) Pentacyclic Triterpenes from the Ethyl Acetate Fraction of the Bark of Platanus acerifolia Wild and Antitumor Activities In Vitro. Mod Chem appl 4: 178. doi:10.4172/2329-6798.1000178

Copyright: (C) 2016 Wang HZ, et al. This is an open-access article distributed unde the terms of the Creative Commons Attribution License, which permits unrestricted use, distribution, and reproduction in any medium, provided the original author and source are credited. 
0.88 (3H, s, H-29), 0.88 (3H, s, H-30), 0.86 (3H, s, H-24), $0.81(3 \mathrm{H}, \mathrm{s}$ $\mathrm{H}-28) ;{ }^{13} \mathrm{C}-\mathrm{NMR}\left(500 \mathrm{MHz}, \mathrm{CDCl}_{3}\right) \delta_{\mathrm{C}}=147.1(\mathrm{C}-13), 120.7(\mathrm{C}-12)$, 78.7 (C-3), 67.6 (C-11), 55.8 (C-9), 55.2 (C-5), 46.9 (C-18), 46.6 (C-19), 45.6 (C-14), 42.8 (C-8), 40.7 (C-1), 39.0 (C-4), 38.8 (C-10), 37.0 (C-22), 34.6(C-21), 33.2 (C-29), 33.0 (C-7), 32.1 (C-17), 31.1 (C-20), 28.5 (C23), 28.1 (C-28), 27.5 (C-2), 27.2 (C-15), 25.6 (C-16), 25.2 (C-27), 23.6 (C-30), 21.0 (C-6), 20.1 (C-26), 18.5 (C-25), 15.6 (C-24). Physical and spectra data of the title compound were almost identical with those reported in the literature [4].

Compound (3): Compound (3), was obtained as colorless crystals. ${ }^{1} \mathrm{H}-\mathrm{NMR}\left(500 \mathrm{MHz}, \mathrm{CDCl}_{3}\right) \delta_{\mathrm{H}}=9.68(1 \mathrm{H}, \mathrm{s}, \mathrm{H}-28), 4.77(1 \mathrm{H}, \mathrm{d}, \mathrm{J}=$ $1.85 \mathrm{~Hz}, \mathrm{H}-29 \mathrm{a}), 4.64(1 \mathrm{H}, \mathrm{d}, \mathrm{J}=1.85 \mathrm{~Hz}, \mathrm{H}-29 \mathrm{~b}), 4.48(1 \mathrm{H}, \mathrm{m}, \mathrm{H}-3)$, $2.86(1 \mathrm{H}, \mathrm{m}, \mathrm{H}-19), 2.06(3 \mathrm{H}, \mathrm{s}, \mathrm{H}-32), 1.70(3 \mathrm{H}, \mathrm{s}, \mathrm{H}-30), 0.98(3 \mathrm{H}, \mathrm{s}$, H-23), 0.93 (3H, s, H-27), 0.86 (3H, s, H-26), 0.85 (3H, s, H-24), 0.84 $(3 \mathrm{H}, \mathrm{s}, \mathrm{H}-25) ;{ }^{13} \mathrm{C}-\mathrm{NMR}\left(500 \mathrm{MHz}, \mathrm{CDCl}_{3}\right) \delta_{\mathrm{C}}=206.6(\mathrm{C}-31), 171.0$ (C-28), 149.7 (C-20), 110.2 (C-29), 80.9 (C-3), 59.3 (C-17), 55.4 (C-5), 50.4 (C-9), 47.5 (C-19), 47.4 (C-18), 42.6 (C-14), 40.8 (C-8), 38.7 (C4), 38.4 (C-1), 38.2 (C-13), 37.8 (C-10), 34.3 (C-22), 33.1 (C-7), 29.9 (C-16), 29.7 (C-15), 29.2 (C-21), 28.8 (C-23), 25.5 (C-2), 23.7 (C-12), 21.3 (C-32), 20.0 (C-11), 19.0 (C-30), 18.2 (C-5), 16.7 (C-25), 16.5. Its relative configuration was further established by X-ray crystallographic analysis [5].

\section{Antitumoral cytotoxic assay}

HepG-2, MCF-7 and HL-60 cell lines were provided by the Nanjing University of Traditional Chinese Medicine Immunization Center. All cell lines were cultured in multi-well plates at $37^{\circ} \mathrm{C}$ in a humidified atmosphere of $5 \% \mathrm{CO}_{2}$ with RPMI-1640 medium containing $10 \%$ fetal bovine serum with $50 \mathrm{U} / \mathrm{mL}$ penicillin and $50 \mu \mathrm{g} / \mathrm{mL}$ streptomycin.

In vitro anti-cell proliferative effects of compound (1) and (2) $11 \alpha$-hydroxy- $\beta$-amyrin were determined on HepG-2, MCF-7 and HL-60 cell lines using the CCK-8 assay. Briefly, cells were counted, transferred into 96 well microtiter plates, and incubated for $24 \mathrm{~h}$ prior to the addition of test compounds. Compounds were dissolved in DMSO and diluted in sterile media, as necessary, to obtain the appropriate concentration. Exponentially growing cells of HepG-2, MCF-7 and HL-60 were made into single cell suspensions with $0.25 \%$ trypsin, at a cell concentration of $1 \times 10^{5} / \mathrm{mL} .90 \mu \mathrm{L}$ cells $\left(9 \times 10^{3}\right)$ were seeded into each well of a 96-well plate. HepG-2, MCF-7 and HL-60 cells were incubated for $24 \mathrm{~h}$ before they were treated with compound (1) and (2) which were in a medium containing 0.1\% DMSO, which showed no inhibitory effect on cell growth. This experiment was performed using 6 different final drug concentrations $(3.125,6.25$, $12.5,25,50,100 \mu \mathrm{M})$. To each well was added $10 \mu \mathrm{L}$ of the appropriate drug. Control cells were treated with an equal volume of serum-free RPMI 1640 containing $0.1 \%$ DMSO. After cells had been cultured for $24 \mathrm{~h}, 10 \mu \mathrm{L}$ CCK-8 was added to each well. One hour later, the cell concentrations were recorded with an automated microplate reader at $450 \mathrm{~nm}$. Each sample was assayed in triplicate, and each assay was repeated twice. Results are expressed as the concentration yielding $50 \%$ inhibition $\left(\mathrm{IC}_{50}\right)$.

$$
\text { The inhibition rate }(\%)=\left[\frac{\left(A_{\text {control }}-A_{\text {experiment }}\right)}{A_{\text {control }}} \times 100 \%\right]
$$

Data were expressed as mean $\pm \mathrm{SD}$. One-way analysis of variances and Fisher's least significant difference was performed using SAS 8.13. Differences were significant at $\mathrm{P}<0.05$.

\section{Results and Discussion}

Compound (1) was readily identified as betulinic acid by the analysis of their NMR spectra and by the comparison with the data reported in literature (Figure 1) [3]. ${ }^{1} \mathrm{H}-\mathrm{NMR}$ and ${ }^{13} \mathrm{C}-\mathrm{NMR}$ spectra showed the typical pattern of pentacyclic triterpene. Especially, the ${ }^{1} \mathrm{H}-\mathrm{NMR}$ spectrum of compound was characteristic of the presence of a vinyl protons at $\delta 5.24(1 \mathrm{H}, \mathrm{d})$ and $4.21(1 \mathrm{H}, \mathrm{dd})$. Two C singlets at $\delta 147.1$ and 120.7 indicated the presence of $\mathrm{C}-\mathrm{C}$ double bond. On the basis of the above evidences, compound (2) was suggested to $11 \alpha$-hydroxy- $\beta$ amyrin. The NMR data of compound was in good agreement with the previous data of 11 $\alpha$-hydroxy- $\beta$-amyrin (Figure 1) [6]. Compound (3), was obtained as colorless crystals. The NMR data of compound (3) was in good agreement with the previous data of $3 \beta$-acetoxy-20 (29)-lupen28-aldehyde [7]. Further single-crystal X-ray diffraction analysis confirmed the molecular structure of compound (3) (Figure 1) [4].

Cell Counting Kit-8 (CCK- 8$)$ is a reagent box used to detect cell proliferation, cell survival and cell toxicity based on a water soluble tetrazolium salt, WST-8\{2-(2-methoxy-4-nitrophenyl)-3-(4nitrophenyl)-5-(2,4-benzene disulfonate)-2H-

tetrazolium monosodium salt\}. CCK-8 is an alternative to MTT assay. During the process of metabolism of living cells, in the presence of 1-methoxy PMS, the WST-8 in cells produces soluble orange formazon. The formazan generated is proportional to the number of living cells. Compared with MTT, CCK- 8 has significant advantages. The formazan generated by MTT is not water-soluble, and requires specific solvents to dissolve it, such as dimethyl sulfoxide. However, formazan generated by CCK-8 solution is water-soluble, and thus organic solvents need not be used in the experiment. On the other hand, CCK- 8 solution is fairly stable, not toxic to cells, and can be used directly $[8]$.

Compound (1), (2) and (3) were evaluated for its cytotoxicity against HepG-2, MCF-7 and HL-60 cancer cell lines by using CCK8 assays and Taxol as positive control (Table 1). Compound (1), (2) and (3) exhibited cytotoxicity against these cell lines and gave $\mathrm{IC}_{50}$ values in the range 2.2-9.1 $\mu \mathrm{M}$. Two pentacyclic triterpenes from the ethyl acetate fraction of the bark of Platanus acerifolia Willd showed potent activities against the tested cancer cell lines. Compound (3) was 4.0 times more toxic to HepG-2 and MCF-7 cells than Compound (1),
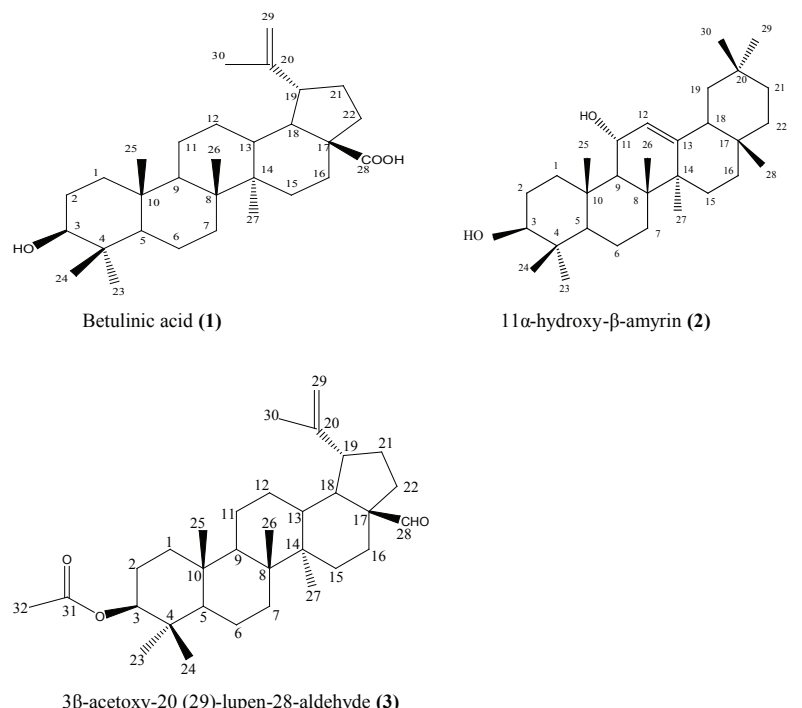

Figure 1: Chemical structure of pentacyclic triterpenes. 
Citation: Wang HZ, Wang CJ, Li W (2016) Pentacyclic Triterpenes from the Ethyl Acetate Fraction of the Bark of Platanus acerifolia Wild and Antitumor Activities In Vitro. Mod Chem appl 4: 178. doi:10.4172/2329-6798.1000178

Page 3 of 3

\begin{tabular}{|c|c|c|c|}
\hline \multirow{2}{*}{ Compounds } & \multicolumn{3}{|c|}{ Growth inhibition constant $\left(\mathbf{I C}_{\mathbf{5 0}}\right)^{\mathbf{a}}$} \\
\cline { 2 - 4 } & HepG-2 & MCF-7 & HL-60 \\
\hline Negative control & $\mathrm{Nt}$ & $\mathrm{Nt}$ & $\mathrm{Nt}$ \\
\hline Solvent control & $\mathrm{Nt}$ & $\mathrm{Nt}$ & $\mathrm{Nt}$ \\
\hline Compound (1) & $9.1 \pm 0.5 \mu \mathrm{M}$ & $8.7 \pm 0.8 \mu \mathrm{M}$ & $6.1 \pm 0.9 \mu \mathrm{M}$ \\
\hline Compound (2) $^{2}$ & $3.0 \pm 0.8 \mu \mathrm{M}$ & $3.1 \pm 0.5 \mu \mathrm{M}$ & $8.9 \pm 1.5 \mu \mathrm{M}$ \\
\hline Compound (3) $^{2}$ & $2.3 \pm 0.3 \mu \mathrm{M}$ & $2.2 \pm 0.2 \mu \mathrm{M}$ & $5.3 \pm 1.0 \mu \mathrm{M}$ \\
\hline Taxol $^{\mathrm{b}}$ & $1.8 \pm 0.4 \mathrm{nM}$ & $5.1 \mathrm{nM}$ & $0.38 \pm 0.2 \mathrm{nM}$ \\
\hline
\end{tabular}

3. Shin SJ, Park CE, Baek NI, Chung IS, Park CH (2009) Betulinic and oleanolic acids isolated from Forsythia suspensa Vahl inhibit urease activity of Helicobacter pylori. Biotechnology Bioprocess Engineering 14: 140-145

4. Yuan X, Wang GL, Gong FJ (1994) Studies on Triterpenoid Constituents Isolated from the Roots of Sabia schumanniana. Acta Botanica Sinica 36: 153158.

5. Wang CJ, Zhu GJ (2012) Isolation and Crystal Structure of $3 \beta$-acetoxy-20 (29)-lupen-28-aldehyde from the bark of Platanus acerifolia Willd. Chinese J Struct Chem 31: 1140-1144.

6. Yelani T, Hussein AA, Meyer JJ (2010) Isolation and identification of poisonous triterpenoids from Elaeodendron croceum. Nat Prod Res 24: 1418-1425.

Table 1: Compound (1), (2) and (3) against cultured HepG-2, MCF-7 and H 60 cancer cell lines. ${ }^{a} \mathrm{C}_{50}$ is defined as the concentration that resulted in a $50 \%$ decrease in cell number and the results are means \pm standard deviation of three independent replicates.

indicating its potential as an anticancer drug. The cytotoxicity of these compounds against some cancer cell lines was previously reported [913].

\section{Acknowledgements}

The authors are grateful to Associate Prof. Hua-Qin Wang of Nanjing University for single-crystal X-ray diffraction analysis. The project was supported by Independent Research Program (Chinese National Scientific Research Training Program-2014).

\section{References}

1. Wang JR, Duan JA, Zhou RH, Tang ML (1998) Chemical constituents from bark of Platanus acerifolia Willd. Plant Resources Environment 7: 59-60.

2. Nishanbaev SZ, Kuliev ZA, Khidyrova NK (2005) New oligomeric proanthocyanidins from bark of Platanus orientalis. Chemistry of Natural Compounds 41: 404-409.

7. Tung NH, Kwon HJ, Kim JH, Ra JC, Kim JA, et al. (2010) An anti-influenza component of the bark of Alnus japonica. Arch Pharm Res 33: 363-367.

8. Yuan YF, Hu XY, He Y, Deng JG (2012) Synthesis and anti-tumor activity evaluation of rhein-aloe emodin hybrid molecule. Nat Prod Commun 7: 207210

9. Tiwari R, Puthli A, Balakrishnan S, Sapra BK, Mishra KP (2014) Betulinic acidinduced cytotoxicity in human breast tumor cell lines MCF-7 and T47D and its modification by tocopherol. Cancer Invest 32: 402-408.

10. Foo JB, Saiful YL, Tor YS, Wibowo A, Ismail N, et al. (2015) Induction of cell cycle arrest and apoptosis by betulinic acid-rich fraction from Dillenia suffruticosa root in MCF-7 cells involved p53/p21 and mitochondrial signalling pathway. J Ethnopharmacol 166: 270-278.

11. Kumar D, Mallick S, Vedasiromoni JR, Pal BC (2010) Anti-leukemic activity of Dillenia indica L. fruit extract and quantification of betulinic acid by HPLC. Phytomedicine 17: 431-435.

12. Fu L, Zhang S, Li N, Wang J, Zhao M, et al. (2005) Three new triterpenes from Nerium oleander and biological activity of the isolated compounds. J Nat Prod 68: $198-206$

13. Moghaddam MG, Ahmad FBH, Samzadeh-Kermani A (2012) Biological Activity of Betulinic Acid: A Review. Pharmacology \& Pharmacy 3: 119-123. 